\title{
SARGASSUM POLYCYSTUM METHANOL EXTRACT AFFECTS THE NUCLEAR FACTOR- $~$ BETA AND INTERLEUKIN-6 EXPRESSION IN STREPTOZOTOCIN-INDUCED DIABETES RATS
}

\author{
MUHAMAD FIRDAUS*, ANIES CHAMIDAH \\ Department of Fish Product Technology, Faculty of Fisheries and Marine Sciences, Brawijaya University, Malang-65145, Indonesia. \\ Email: muhamadfir@ub.ac.id
}

Received: 02 June 2018, Revised and Accepted: 18 July 2018

\section{ABSTRACT}

Objective: The objective of this study is to investigate the attenuation of the nuclear factor- $\kappa$ beta (NF- $\kappa \mathrm{B}$ ) and interleukin (IL)-6 expression in streptozotocin-induced diabetic rats by Sargassum polycystum methanol extract.

Methods: Diabetic rats were intraperitoneally induced by streptozotocin ( $40 \mathrm{mg} / \mathrm{kg}$ b.w.). S. polycystum methanol extract was administered to diabetic rats for 45 days. The effect of $S$. polycystum methanol extract on blood glucose, hemoglobin $A_{1 c}\left(H_{b} A_{1 c}\right)$, NF- $\kappa B$, and IL- 6 expression was investigated on streptozotocin-induced diabetic rats. The gliclazide (30 mg/kg b.w., p.o.) was used as a reference antidiabetic drug.

Results: The administration of $S$. polycystum methanol extract on streptozotocin-induced diabetic rats decreased the blood glucose level, HbA ${ }_{1 c^{\prime}}$ NF- $\mathrm{KB}$, and IL-6.

Conclusion: S. polycystum methanol extract indicates a promising anti-inflammation agent in diabetes.

Keywords: Diabetes mellitus, Free radical, Inflammation, Sargassum polycystum.

(C) 2018 The Authors. Published by Innovare Academic Sciences Pvt Ltd. This is an open access article under the CC BY license (http://creativecommons. org/licenses/by/4. 0/) DOI: http://dx.doi.org/10.22159/ajpcr.2018.v11i11.27658

\section{INTRODUCTION}

Hyperglycemia can provoke inflammation, where the complications in diabetes are always initiated by this occurrence $[1,2]$. The inflammation on diabetes can be induced by the formation of advanced glycation end products, such as hemoglobin $\mathrm{A}_{1 \mathrm{c}}\left(\mathrm{HbA}_{1 \mathrm{c}}\right)$ [3], and then the formation of these radicals elicits the nuclear factor- $\kappa$ beta $(\mathrm{NF}-\mathrm{\kappa B})$ activation. This cytokine can activate pro-inflammatory cytokines such as interleukin (IL)-6 [4]. The administration of oral hypoglycemic agents or insulin has been known to be able to control blood glucose and effective to prevent inflammation in diabetics. However, its use chronically stimulates the side effects [5]. Efforts must be taken, therefore, to discover and develop new hypoglycemic agents that do not coincide with inflammation.

Sargassum polycystum is a brown seaweed that grows in lower intertidal zones of warm tropical waters. This seaweed grows to a height of around 1-2 m, having erect branches and stems with numerous spines $[6,7]$. The methanol extract of this seaweed contains numerous phytochemical compounds such as steroids, alkaloids, phenolics, flavonoids, saponins, and sterols [8]. Previous studies had shown that the methanol extract of this seaweed is considered nontoxic [9], having antioxidant activity [10], hypoglycemic action [11], and oxidative stress amelioration [12].

The evaluation of this brown seaweed methanol extract on the attenuation of inflammation in diabetes appears to lack information. Therefore, this study was undertaken to investigate the amelioration role of $S$. polycystum methanol extract on the inflammation in diabetic rats.

\section{METHODS}

\section{Plant material}

S. polycystum was collected from Talango coastline, Sumenep District, East Java, Indonesia, in March 2016. This seaweed was authenticated by AchmadKadi, the phycologist at the Research Center for Oceanography, Indonesian Institute of Sciences (Identification No. 498/IPK.2/LT.02.04/XII).

\section{Preparation of extract}

The collected sample was sun-dried, powdered by dish mill and passed through a sieve, and macerated by methanol $(1: 3 ; \mathrm{b} / \mathrm{v})$ 3 times for $24 \mathrm{~h}$ at $4^{\circ} \mathrm{C}$. The extract was further concentrated to a semisolid form using a rotary vacuum evaporator, and then, it was flashed by nitrogen gas and finally freeze-dried by lyophilization to obtain the SPME.

\section{Standard drug}

Gliclazide tablets (Diamicron 30 MR, Servier, Laboratories Ltd.) are one of the group of sulfonylurea compounds used as the standard drug. This was purchased from Kimia Farma Pharmacy, Malang. The tablets were suspended in sesame oil and used for the experiment.

\section{Animals}

Male species of Rattus norvegicus strain Wistar with body weights ranging from 180 to $200 \mathrm{~g}$ were used in this study. The animal experiments were conducted according to the Institutional Ethics Committee of Animal Care and Use, Brawijaya University, Malang, Indonesia (No: 510-KEP-UB). The rats were acclimatized for 7 days before the study and housed in polypropylene cages under an ambient temperature. The rats were kept on a standard pellet diet and water ad libitum.

\section{Induction of diabetes}

Rats were induced diabetes by single intraperitoneal injection of streptozotocin (bioWORLD) (40 mg/kg) in fresh citrate buffer $(\mathrm{pH}=4.5)$ after overnight fasting. After 10 days of injection, rats showing blood glucose level $>200 \mathrm{mg} / \mathrm{dl}$ were selected in the study and considered as diabetic, while the rats with a blood glucose $<200 \mathrm{mg} / \mathrm{dl}$ were excluded from this study. 
Table 1: Effect of SPME on blood glucose in streptozotocin-induced diabetic rats

\begin{tabular}{|c|c|c|c|c|c|c|c|}
\hline \multirow[t]{2}{*}{ Groups } & \multicolumn{7}{|c|}{ Mean blood glucose level in $\mathrm{mg} / \mathrm{dl}$ at different time intervals } \\
\hline & Treatment (mg/kg) & 0 day & $9^{\text {th }}$ day & $18^{\text {th }}$ day & $27^{\text {th }}$ day & $36^{\text {th }}$ day & $45^{\text {th }}$ day \\
\hline Normal control & Sesame oil, p.o. & $119.8 \pm 8.2$ & $118 \pm 8.1$ & $118.4 \pm 8.4$ & $121.2 \pm 8.8$ & 112.48 .0 & $114.0 \pm 7.9$ \\
\hline Diabetic control & Sesame oil, p.o. & $503.0 \pm 17.4^{*}$ & $506.0 \pm 16.9 *$ & $538.2 \pm 18.2^{*}$ & $545.4 \pm 17.8^{*}$ & $556.8 \pm 13.8^{*}$ & $566.8 \pm 13.9 *$ \\
\hline Gliclazide & 30, p.o. & $519.4 \pm 21.9^{*}$ & $512.4 \pm 19.6^{*}$ & $406.8 \pm 15.2^{*+}$ & $250.8 \pm 10.8^{*+}$ & $205.4 \pm 8.5^{* \dagger}$ & $176.0 \pm 6.6^{*+}$ \\
\hline SPME & 600, p.o. & $507.4 \pm 19.2^{*}$ & $494.2 \pm 17.8^{*}$ & $454.6 \pm 16.5^{* \dagger}$ & $363.4 \pm 14.4^{* \dagger}$ & $280.8 \pm 10.7^{* \dagger}$ & $206.4 \pm 7.5^{* \dagger}$ \\
\hline
\end{tabular}

Data were expressed as mean \pm SEM, $(n=5) .{ }^{*} \mathrm{p}<0.05$ versus $N C,{ }^{\dagger} \mathrm{p}<0.05$ versus DC. SEM: Standard error of the mean

Table 2: Effect of SPME on $\mathrm{HbA}_{1 c^{\prime}}, \mathrm{NF}-\mathrm{KB}$, and IL-6 in streptozotocin-induced diabetic rats

\begin{tabular}{|c|c|c|c|c|}
\hline \multirow[t]{2}{*}{ Groups } & Treatment & $\mathrm{HbA}_{1 \mathrm{c}}$ & NF- $\kappa B$ & IL-6 \\
\hline & $(\mathrm{mg} / \mathrm{kg})$ & $(\%)$ & 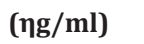 & $(\rho g / m l)$ \\
\hline $\begin{array}{l}\text { Normal } \\
\text { control }\end{array}$ & Sesame oil, p.o. & $5.37 \pm 0.10$ & $1.5 \pm 0.03$ & $13.6 \pm 0.51$ \\
\hline $\begin{array}{l}\text { Diabetic } \\
\text { control }\end{array}$ & Sesame oil, p.o. & $16.65 \pm 0.31 *$ & $4.8 \pm 0.08^{*}$ & $81.8 \pm 3.04^{*}$ \\
\hline Gliclazide & $30, p$ & $7.11 \pm 0.1$ & $2.3 \pm 0.04^{* \dagger}$ & $24.6 \pm 0.93^{*}$ \\
\hline SPME & 600, p.o. & $9.09 \pm 0.17^{* \dagger}$ & $3.8 \pm 0.07^{* \dagger}$ & $43.4 \pm 1.61^{*}$ \\
\hline
\end{tabular}

Data were expressed as mean \pm SEM, $(n=5) .{ }^{*} \mathrm{p}<0.05$ versus $\mathrm{NC},{ }^{\dagger} \mathrm{p}<0.05$ versus

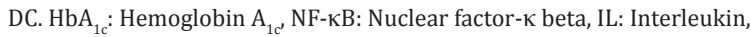

SEM: Standard error of the mean

\section{Experimental design}

Four groups of five rats each were distributed to the following treatments for 45 days - Group 1: Healthy normal rats received only sesame oil, Group 2: Diabetic control rats received only sesame oil, Group 3: Diabetic rats treated with gliclazide $30 \mathrm{mg} / \mathrm{kg}$ body weight/day orally, and Group 4: Diabetic rats treated with $600 \mathrm{mg} / \mathrm{kg}$ of SPME, respectively. The blood sample was obtained from the tails of rats. The blood glucose of rats was determined by glucometer (GlucoDr BioSensor AGM-2100) every 9 days during the experiment period. The blood of rats was acquired from the heart by puncture, and then, the serum was obtained by the centrifugation of the blood. The serum was stored at $-80^{\circ} \mathrm{C}$ until it was used for cytokines analysis.

$\mathrm{HbA}_{1 \mathrm{c}}$

$\mathrm{HbA}_{1 \mathrm{c}}$ of serum was determined using Cobas Integra 400 Plus, Roche Diagnostics Ltd., Switzerland.

\section{NF- $\mathrm{KB}$ and IL-6}

NF- $\kappa \mathrm{B}$ and IL-6 levels of serum were determined by ELISA kits (Bioassay Technology Laboratory No E0287Ra for NF- $\mathrm{kB}$ analysis and Bioassay Technology Laboratory No E0135Ra for IL-6 determination [Shanghai, China]), and the protocol of assay followed the manual of kits. The absorbance of the cytokine solutions was read using Bio-Rad Model 680 microplate reader.

\section{Statistical analysis}

Data of this study were stated as mean \pm standard error mean. The difference among treatments was analyzed by the analysis of variance and followed by the least square difference test. The significance level was set at $\mathrm{p}<0.05$

\section{RESULTS}

Effect of SPME on blood glucose in streptozotocin-induced diabetic rats

The effect of SPME on blood glucose in streptozotocin-induced diabetic rats is shown in Table 1 . This study showed the SPME treatments on diabetic rats significantly reduced the blood glucose level after the $18^{\text {th }}$ day compared to the diabetic control. Diabetic control showed a significant increase in the blood glucose when compared to normal.
Effect of SPME on $\mathrm{HbA}_{1 \mathrm{c}}$ levels in streptozotocin-induced diabetic rats

Table 2 shows that SPME diminished significantly on the $\mathrm{HbA}_{1 \mathrm{c}}$ level of streptozotocin-induced diabetic rats when compared to diabetic control. The $\mathrm{HbA}_{1 \mathrm{c}}$ level on diabetic rats was diminished by the SPME treatments. Diabetic control exhibited the highest level of the $\mathrm{HbA}_{1 \mathrm{c}}$ among other treatments.

Effect of SPME on NF-אB and IL-6 levels in streptozotocin-induced diabetic rats

The decrease of NF-KB and IL-6 expression in streptozotocin-induced diabetic rats was affected by SPME (Table 2). The expression of NF- $\kappa \mathrm{B}$ and IL- 6 on diabetic rats was reduced by gliclazide as well. The inflammation level on diabetic control showed the strongest level compared to other treatments.

\section{DISCUSSION}

The blood glucose level of diabetic rats was higher than normal. The treatment of streptozotocin injection causes hyperglycemia on the normal rats [13]. Usage of gliclazide reduced the blood glucose level on the diabetic rats by enhancing insulin secretion. The blood glucose of diabetic rats which were treated with SPME showed a decrease. Phenolics in SPME reveal the insulin-mimicking effect [14], so the blood glucose level in diabetic rats decreased.

Hyperglycemia in diabetic rats caused the increase in advanced glycation end products formation, such as $\mathrm{HbA}_{1 c}$ [15]. The hypoglycemic capability of gliclazide affected this $\mathrm{Hb}$ level in diabetic rats. This drug is also able to eliminate the free radical, so the production of this glycation product will decrease. SPME contains phenolics, where these compounds are capable as insulin-mimicking and antioxidant agents. The importance of these activities is the inhibition and reduction of glycation product in the $\mathrm{Hb}$ [16].

Inflammation can be induced by high blood glucose in diabetics. The NF- $\kappa B$ and IL- 6 expression in the diabetic rats was the highest among the other treatments. Gliclazide belongs to insulin secretagogues, so the blood glucose level of diabetics decreased. This reduction will diminish the inflammation in diabetics. The diabetic rats treated with SPME showed the decrease of NF- $\mathrm{KB}$ and IL- 6 expressions. These phenomena can be affected by the decrease of blood glucose by SPME in diabetic rats, where one of the inflammation causes in diabetes is hyperglycemia.

Thus, the present study proves that the S. polycystum methanol extract exhibits potency and demonstrates the prevention of inflammation in diabetes.

\section{ACKNOWLEDGMENT}

This study is financially supported by Penelitian Berbasis Kompetensi Grant No. 33/SP2H/LT/DRPM/II/2016 from the Ministry of Research, Technology and Higher Education, Republic of Indonesia.

\section{AUTHORS' CONTRIBUTION}

Dr. Muhamad Firdaus - He was the principal investigator of this present study. He prepared the manuscript drafting and treated the diabetic animal model. Dr. AniesChamidah - She contributed on the blood and cytokines analysis, data collection, analysis, and interpretation. 


\section{CONFLICTS OF INTERESTS}

Authors declare no conflicts of interest.

\section{REFERENCES}

1. Domingueti CP, Dusse LM, Carvalho MD, de Sousa LP, Gomes KB, Fernandes AP, et al. Diabetes mellitus: The linkage between oxidative stress, inflammation, hypercoagulability and vascular complications. J Diabetes Complications 2016;30:738-45.

2. Saad EA, Habib SA, Refai WA, Elfayoumy AA. Malondialdehyde, adiponectin, nitric oxide, c-reactive protein, tumor necrosis factoralpha and insulin resistance relationships and interrelationships in Type 2 diabetes early stage. Is metformin alone adequate in this stage? Int J Pharm Pharm Sci 2017;9:176-81.

3. Byun K, Yoo Y, Son M, Lee J, Jeong GB, Park YM, et al. Advanced glycation end-products produced systemically and by macrophages: A common contributor to inflammation and degenerative diseases. Pharmacol Ther 2017;177:44-55.

4. Daroux M, Prévost G, Maillard-Lefebvre H, Gaxatte C, D'Agati VD, Schmidt AM, et al. Advanced glycation end-products: Implications for diabetic and non-diabetic nephropathies. Diabetes Metab 2010;36:1-0.

5. Pittman JM, Schalliol LA, Ray SD. Insulin and other hypoglycemic drugs. Side Eff Drugs Annu 2017;39:435-46.

6. Ateweberhan M, Bruggemann JH, Breeman AM. Seasonal changes in size structure of Sargassum and Turbinaria populations (Phaeophyceae) on tropical reef flats in the southern red sea. J Phycol 2009;45:69-80.

7. Mattio L, Anderson RJ, Bolton JJ. A revision of the genus Sargassum (Fucales, Phaeophyceae) in South Africa. South Afr J Botany
2015;98:95-107.

8. Kanimoshi AS, Johnson M, Malar RJ. Phytochemical composition of Sargassum polycystum and Sargassum duplicatum J. Agardh. Int J Pharm Pharm Sci 2015;7:393-7.

9. Firdaus M, Astawan M, Muchtadi D, Wresdiyati T, Waspadji S, Karyono SS. Acute oral toxicity of methanol extract from brown algae Sargassum echinocarpum. J Pengol Hasil Perik Indo 2012;15:148-55.

10. Firdaus M. Antioxidant activity index of brown seaweed (Sargassum aquifolium) extract. J Pengol Hasil Perik Indo 2013;16:24-7.

11. Liu L, Heinrich M, Myers S, Dworjanyn SA. Towards a better understanding of medicinal uses of the brown seaweed sargassum in traditional Chinese medicine: A phytochemical and pharmacological review. J Ethnopharmacol 2012;142:591-619.

12. Firdaus M, Soeharto S. Sargassum polycystum extract attenuates oxidative stress on diabetic rats. J Coast Life Med 2016;4:944-8.

13. Mishra A, Gautam S, Pal S, Mishra A, Rawat AK, Maurya R, et al. Effect of Momordicacharantia fruits on streptozotocin-induced diabetes mellitus and its associated complications. Int J Pharm Pharma Sci 2015;7:356-63

14. Zhao C, Yang CF, Liu B, Lin L, Sarker SD, Nahar L, et al. Bioactive compounds from marine macroalgae and their hypoglycemic benefits. Trends in Food Sci Tech 2018;72:1-12.

15. Surana YS, Ashok P, Rajendran R. Evaluation of antidiabetic, hypolipidemic and antioxidant activity of polyherbal formulation in streptozotocin-nicotinamide induced diabetes in rats. Int J Pharm Pharm Sci 2017;9:105-10.

16. Yeh WJ, Hsia SM, Lee WH, Wu CH. Polyphenols with antiglycation activity and mechanisms of action: A review of recent findings. J Food Drug Anal 2017;25:84-92. 